\title{
Automatic Load Frequency Control in Three Area Power System using PID Controller
}

\author{
Shallu Sharma ${ }^{1}$ and Jitendra Bhadoriya ${ }^{2}$ \\ Department of Electrical And Electronics Engineering, Rajiv Gandhi Technical University, Bhopal, MP ${ }^{1,2}$
}

\begin{abstract}
In this paper, the dynamic performance of automatic load frequency control of three-area power system is done by using PID controller. When load changes then, there is drift in system frequency and voltage which in turn leads to loss in generation owing to blackouts and line tripping. Main objectives of automatic load frequency control in each area is to supply load demand and to minimize tie-line power deviations, to minimize transient deviations, to improve steady-state error and to match the output power of generator with change in load. Thus, simulation evaluation is done to know the working of ALFC by building simulink models in single area, two area and three area power system.
\end{abstract}

Index terms: Automatic Load frequency control, Area control error (ACE), Proportional integral derivative (PID) controller, Matlab/Simulation.

\section{NOMENCLATURE: \\ $\Delta \mathrm{p}_{\text {ref }} \quad=$ Incremental speed reference setting \\ $\Delta \mathrm{p}_{\mathrm{m}} \quad=$ Turbine output \\ $\Delta \mathrm{p}_{\mathrm{G}} \quad=$ Active power generation \\ $\Delta \mathrm{p}_{\mathrm{D}} \quad=$ Active power demand \\ $\Delta \mathrm{p}_{\mathrm{V}} \quad=$ Input to the turbine \\ $\Delta \mathrm{p}_{\mathrm{T}} \quad=$ Output from the turbine \\ $\mathrm{P}_{12} \quad=$ Power due to tie-lines \\ $\mathrm{Tg}=$ time constant of the generator}

\section{INTRODUCTION}

Automatic load frequency control (ALFC) is very important issue in power system operation and control for supplying sufficient and reliable electric power with good quality. ALFC is basically the active power control and the frequency control. The interconnected areas of power system are divided in to three areas that are governor, turbine and generator. These all form a coherent group. In electrical power system, LFC is used for automatic generation control. One of the objectives of $\mathrm{AGC}$ is that there should be adjustable frequency in each area according to the control and each area should accomplish its individual demand in load. The load demand increases or decreases in form of the kinetic energy which is stored in generator which results in variation of frequency and speed accordingly. Thus, for the safe operation of power system, the aim is to control the frequency. Since, load demand varies without prior schedule. So, frequency and voltage controller are required to maintain the generated power quality so, as to supply constant voltage and frequency to the grid.

\section{LOAD-FREQUENCY CONTROL}

Basically, automatic load controller determines control parameters, or determines actual value to a desired value or defines deviations in order to have deviations to be zero so that control parameters can be obtained. Main function of load frequency is to ensure stable and reliable operation of power system. The PID controller is very simple for implementation and gives better dynamic response. In a system if load occurs, the frequency also changes. If it was not important to keep frequency to a steady state or constant then, no regulation control would be required. Normally the frequency would vary by $5 \%$ approx. from light load to full load conditions. So, for the satisfactory operation of the system there should be frequency control so, that in parallel motors should run at a desired speed and time is noted by using synchronous clock.

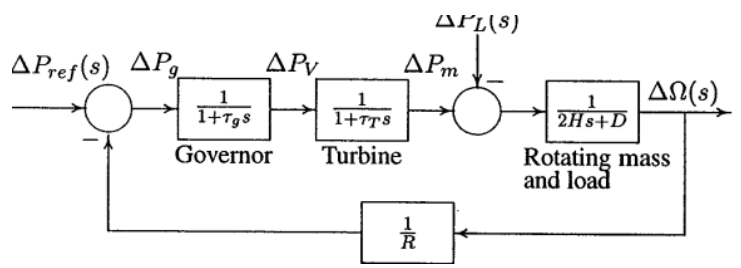

Fig.2.1 Block diagram of Automatic load frequency control

Automatic load frequency control is associated with large sized generators. Main aim of ALFC is to have frequency control so as to divide the loads among generators in order to have exchange of tie-line power $\mathrm{n}$ accordance to the scheduled values. Primary control loop reacts to frequency changes through the speed governor and the hydro flow is managed. Thus speed, and frequency control is performed by primary loop. Secondary loop is slower as compared to primary loop. Excellent regulation of frequency is maintained by secondary loop. This loop is insensitive to load changes as well as frequency.

\section{PID Controller}

PID is known as proportional integral derivative controller. In proportional control action, the output of controller have continuous linear relationship with the actuating error signal (e).This is also known as amplifier with adjustable gain. In integral control action, the output of the controller is proportional to the actuating signal. This is also known as reset controller. In derivative control action, the output of the controller depends upon the actuating signal. PID controller is found to be superior over integral controller for automatic load frequency control(ALFC) because it has less oscillations, good dynamic response, improved steady-state error, reduce transient deviations and less settling time. 


\section{SIMULATION RESULTS}

B using simulation models we can obtain the performance characteristics of the system very easily and quickly for analysis purpose. Below are the various simulink models with their respective response plotted against time for single area, two areas and for three areas power system.

(a) For Single area system:-

\begin{tabular}{|l|l|l|l|l|l|l|l|}
\hline Name & $\mathrm{Kg}$ & $\begin{array}{l}\mathrm{Tg} \\
(\mathrm{s})\end{array}$ & $\mathrm{Kt}$ & $\begin{array}{l}\mathrm{Tt} \\
(\mathrm{s})\end{array}$ & $\begin{array}{l}\mathrm{H} \\
(\mathrm{s})\end{array}$ & $\begin{array}{l}\mathrm{D} \\
(\mathrm{puM} \\
\mathrm{W} / \mathrm{Hz})\end{array}$ & $1 / \mathrm{R}$ \\
\hline Value & 1 & 0.2 & 1 & 0.5 & 5 & 0.80 & 30 \\
\hline
\end{tabular}

TABLE 4.1: System parameters for Single Area System without using secondary control

\begin{tabular}{|l|l|l|l|l|l|l|l|l|}
\hline Name & $\begin{array}{l}\mathrm{K} \\
\mathrm{g}\end{array}$ & $\begin{array}{l}\mathrm{Tg} \\
(\mathrm{s})\end{array}$ & $\begin{array}{l}\mathrm{K} \\
\mathrm{t}\end{array}$ & $\begin{array}{l}\mathrm{Tt} \\
(\mathrm{s})\end{array}$ & $\begin{array}{l}\mathrm{H} \\
(\mathrm{s})\end{array}$ & $\begin{array}{l}\mathrm{D} \\
(\mathrm{pu} \\
\mathrm{MW} \\
/ \mathrm{Hz})\end{array}$ & $\mathrm{I} / \mathrm{R}$ & $\begin{array}{l}\mathrm{K} \\
1\end{array}$ \\
\hline Value & 1 & 0.2 & 1 & 0.5 & 5 & 0.80 & 20 & 7 \\
\hline
\end{tabular}

TABLE 4.2: System parameters for Single Area System by using secondary control

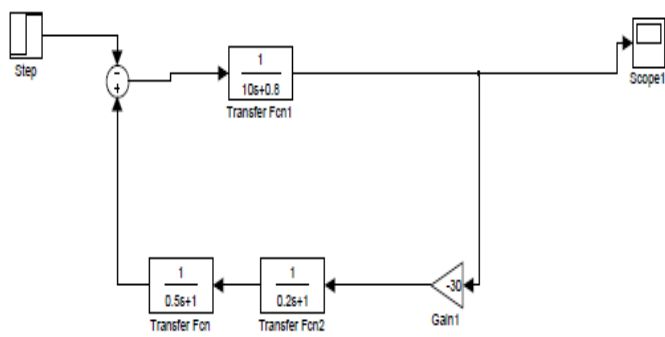

Fig.4.1: Simulink model of single area system without using secondary loop

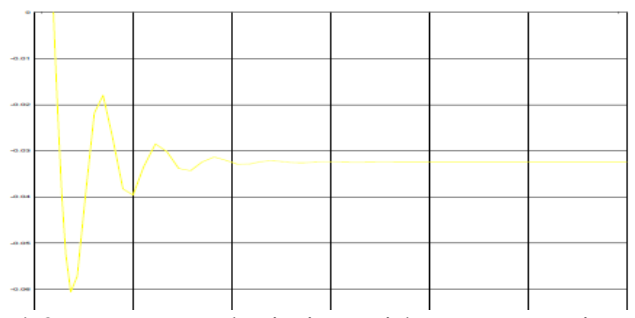

Fig.4.2 Frequency deviation with respect to time

The plot in fig. 4.2 which is obtained from simulating model from fig. 4.1 shows that change in frequency causes change in speed and frequency deviation. We have taken different values of parameters as shown in fig. 4.1.

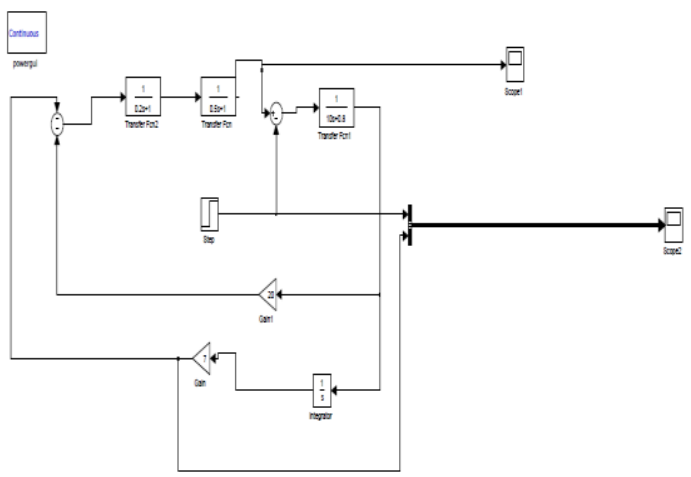

Fig. 4.3 Simulink model by using secondary loop

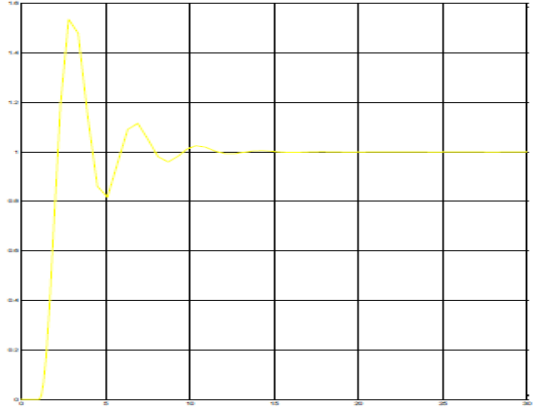

Fig. 4.4 Change in turbine output with respect to time Fig.4.3 an integer controller by means of gain 1.e $\mathrm{Ki}$ is used to regulate the signal of speed reference $\Delta \mathrm{p}_{\text {ref }}$ so, that frequency deviation to be zero. Drift in frequency is brought to be zero because of integral loop. Values of different parameters have been taken shown in the fig. 4.3.

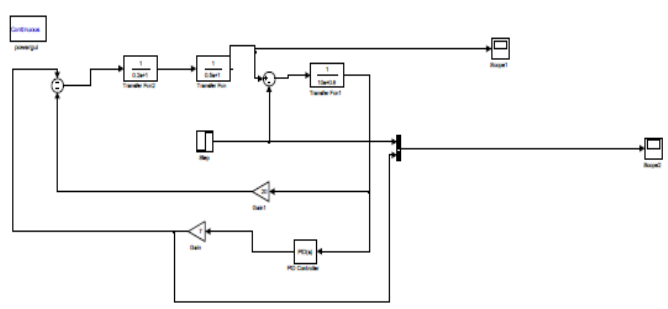

Fig. 4.5 Simulink Model using PID

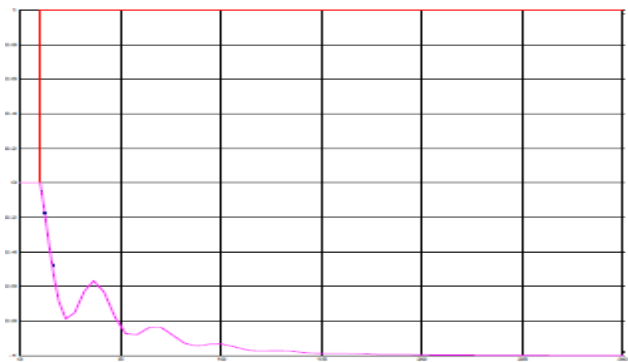

Fig. 4.6 Change in Frequency with respect to time

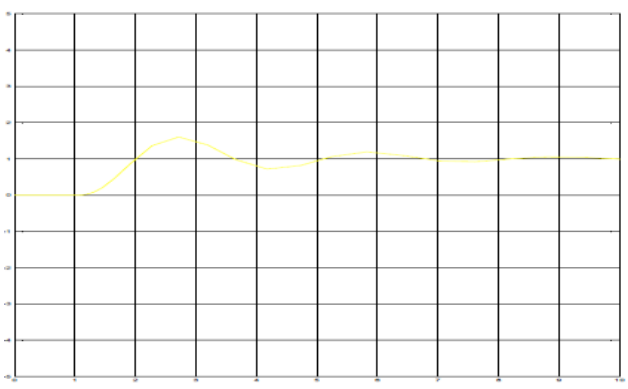

Fig. 4.7 power deviation vs. time

Fig. 4.5 shows PID controller by setting proportional gain $\mathrm{K}_{\mathrm{p}}$ to 1.0 and adjust $\mathrm{K}_{\mathrm{i}}$ and $\mathrm{K}_{\mathrm{D}}$ until a step response with a min. overshoot and very small settling time is obtained.

(b) For Two Area Power System:-

\begin{tabular}{|l|l|l|l|l|l|l|l|l|}
\hline Name & $\mathrm{Kg}$ & $\begin{array}{l}\mathrm{Tg} \\
(\mathrm{s})\end{array}$ & $\begin{array}{l}\mathrm{K} \\
\mathrm{t}\end{array}$ & $\begin{array}{l}\mathrm{Tt} \\
(\mathrm{s})\end{array}$ & $\begin{array}{l}\mathrm{H} \\
(\mathrm{s})\end{array}$ & $\begin{array}{l}\mathrm{D} \\
(\mathrm{puM} \\
\mathrm{W} / \mathrm{H} \\
\mathrm{z})\end{array}$ & $\begin{array}{l}1 / \\
\mathrm{R}\end{array}$ & $\begin{array}{l}\Delta \mathrm{PL} \\
(\mathrm{p} . \mathrm{u} \\
)\end{array}$ \\
\hline Area1 & 1 & 0.20 & 1 & 0.50 & 5 & 0.60 & 20 & 0 \\
\hline Area2 & 1 & 0.30 & 1 & 0.60 & 4 & 0.90 & 16 & 1 \\
\hline
\end{tabular}

TABLE 4.3: System parameters for two area system without using secondary control 
INTERNATIONAL JOURNAL OFINNOVATIVE RESEARCH IN ELECTRICAL, ELECTRONICS, INSTRUMENTATION AND CONTROL ENGINEERING Vol. 3, Issue 8, August 2015

\begin{tabular}{|l|l|l|l|l|l|l|l|l|l|}
\hline Name & $\begin{array}{l}\mathrm{K} \\
\mathrm{g}\end{array}$ & $\begin{array}{l}\mathrm{Tg} \\
(\mathrm{s})\end{array}$ & $\mathrm{Kt}$ & $\begin{array}{l}\mathrm{Tt} \\
(\mathrm{s})\end{array}$ & $\begin{array}{l}\mathrm{H} \\
(\mathrm{s} \\
)\end{array}$ & $\begin{array}{l}\mathrm{D} \\
(\mathrm{pu} \\
\mathrm{MW} \\
/ \mathrm{Hz})\end{array}$ & $\begin{array}{l}1 / \\
\mathrm{R}\end{array}$ & $\begin{array}{l}\Delta \mathrm{P} \\
(\mathrm{p} . \\
\mathrm{u})\end{array}$ & $\begin{array}{l}\mathrm{K} \\
1\end{array}$ \\
\hline Area1 & 1 & 0.20 & 1 & 0.50 & 5 & 0.60 & 20 & 0 & 7 \\
\hline Area2 & 1 & 0.30 & 1 & 0.60 & 4 & 0.90 & 16 & 1 & 7 \\
\hline
\end{tabular}

TABLE 4.4: System parameters for two area system by using secondary control

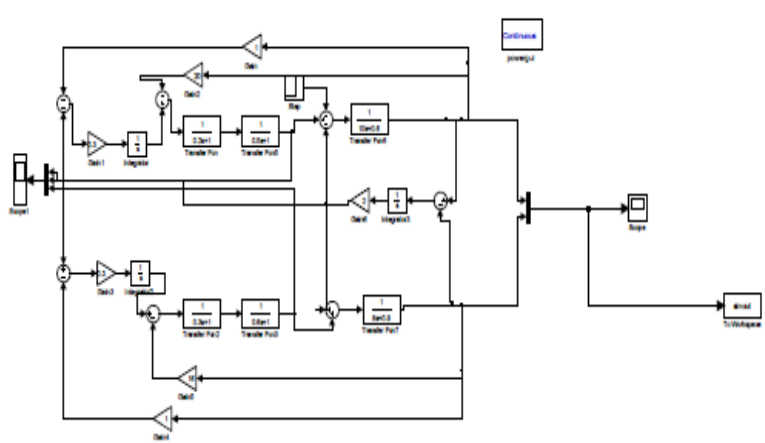

Fig. 4.7 Simulink Model of two area system without integral loop

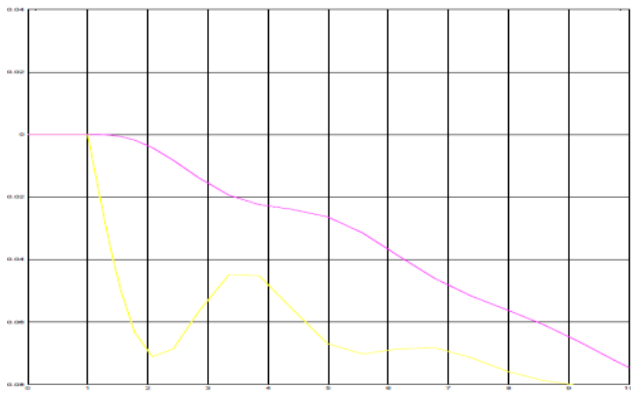

Fig. 4.8 Frequency deviation vs. time

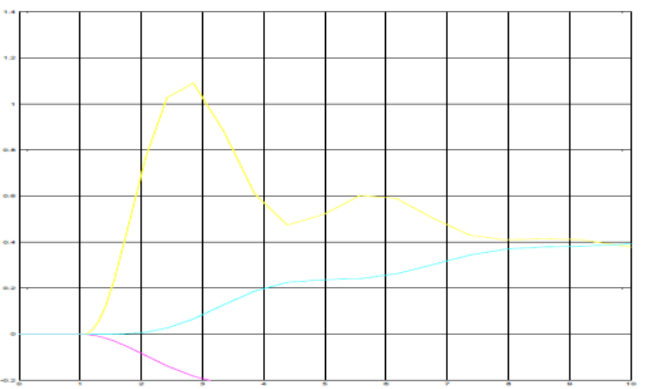

Fig. 4.9 Power deviation vs. time

Fig. 4.8 shows that after few oscillations the drift in the frequency will settle down for the interconnected system. Area 1 is capable to reduce the inequality power connected to the load and area 2 is capable of generating excessive power to distribute the variation in load in area 1 . Different values of parameters have been taken.

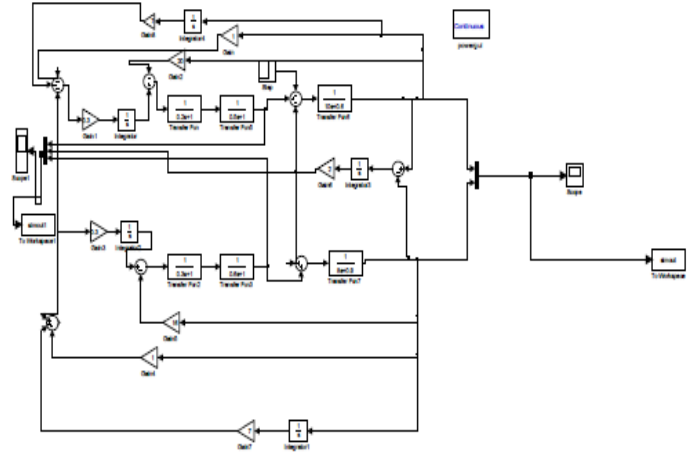

Fig. 4.10 Simulink model with integral loop

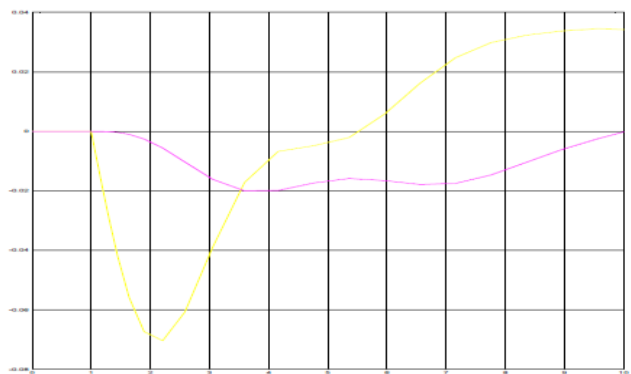

Fig. 4.11 Frequency deviation vs. time

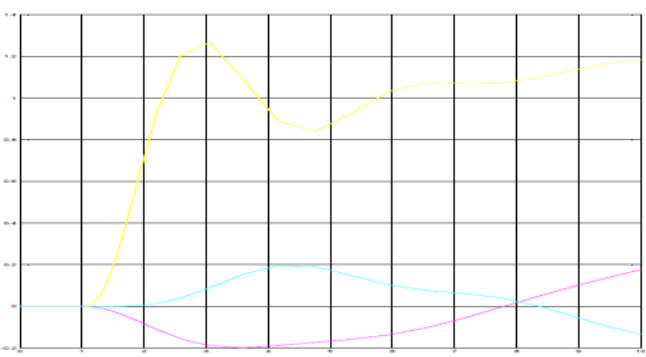

Fig. 4.12 Power deviation vs. time

Fig. 4.10 shows two area power system using integral loop. Drift in frequency made to be zero by using secondary loop shown in 4.11. By changing the secondary loop gain we can see the variation in dynamic response characteristic shown in fig. 4.12. Different values of parameters have been taken.

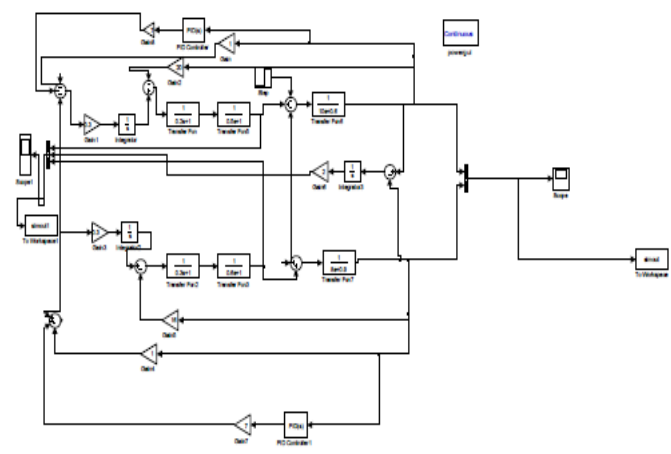

Fig. 4.13 Simulink model using PID 


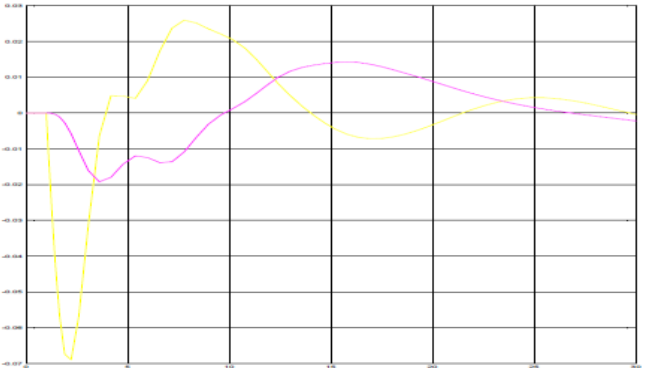

Fig. 4.13 Frequency deviation vs. time

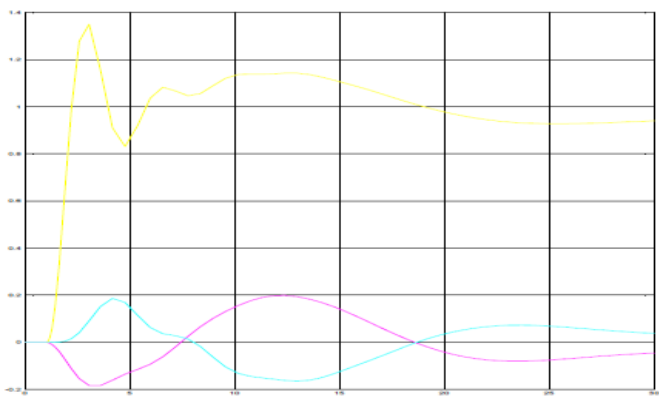

Fig. 4.14 power deviation vs. time

Fig. 4.12 shows simulink model of two area power system using PID controller. PID controller is used over integral because it gives less oscillations, good dynamic response and very small settling time.

(c) For Three Area Power System:-

\begin{tabular}{|l|l|l|l|l|l|l|l|l|}
\hline Name & $\mathrm{Kg}$ & $\begin{array}{l}\mathrm{Tg} \\
(\mathrm{s})\end{array}$ & $\mathrm{Kt}$ & $\begin{array}{l}\mathrm{Tt} \\
(\mathrm{s})\end{array}$ & $\begin{array}{l}\mathrm{H} \\
(\mathrm{s})\end{array}$ & $\begin{array}{l}\mathrm{D} \\
(\mathrm{pu} \\
\mathrm{M} \\
\mathrm{W} /\end{array}$ & $\begin{array}{l}1 / \mathrm{R} \\
\mathrm{Hz})\end{array}$ & $\begin{array}{l}\Delta \mathrm{P} \\
\mathrm{L}( \\
\mathrm{p.u} \\
)\end{array}$ \\
\hline Area1 & 1 & 0.80 & 1 & 0.30 & 10 & 1.00 & 15 & 1 \\
\hline Area2 & 1 & 0.20 & 1 & 0.50 & 5 & 0.60 & 20 & 0 \\
\hline Area3 & 1 & 0.30 & 1 & 0.60 & 4 & 0.90 & 16 & 0 \\
\hline
\end{tabular}

TABLE 4.5: System parameters for three area system without using secondary control

\begin{tabular}{|l|l|l|l|l|l|l|l|l|l|l|}
\hline Name & $\begin{array}{l}\mathrm{K} \\
\mathrm{g}\end{array}$ & $\begin{array}{l}\mathrm{Tg} \\
(\mathrm{s})\end{array}$ & $\begin{array}{l}\mathrm{K} \\
\mathrm{t}\end{array}$ & $\begin{array}{l}\mathrm{Tt} \\
(\mathrm{s})\end{array}$ & $\begin{array}{l}\mathrm{Tp} \\
(\mathrm{s})\end{array}$ & $\begin{array}{l}\mathrm{H} \\
(\mathrm{s})\end{array}$ & $\begin{array}{l}\mathrm{D} \\
(\mathrm{pu} \\
\mathrm{MW} \\
/ \mathrm{Hz})\end{array}$ & $\begin{array}{l}\mathrm{K} \\
\mathrm{i}\end{array}$ & $\begin{array}{l}1 / \\
\mathrm{R}\end{array}$ & $\begin{array}{l}\Delta \\
\mathrm{P} \\
\mathrm{L}( \\
\mathrm{p} . \\
\mathrm{u})\end{array}$ \\
\hline Area1 & 1 & 0.80 & 1 & 0.30 & 20 & 10 & 1.00 & 7 & 17 & 1 \\
\hline Area2 & 1 & 0.20 & 1 & 0.50 & 10 & 5 & 0.60 & 7 & 20 & 0 \\
\hline Area3 & 1 & 0.30 & 1 & 0.60 & 8 & 4 & 0.90 & 7 & 16 & 0 \\
\hline
\end{tabular}

TABLE 4.6: System parameters for three area system without using secondary control

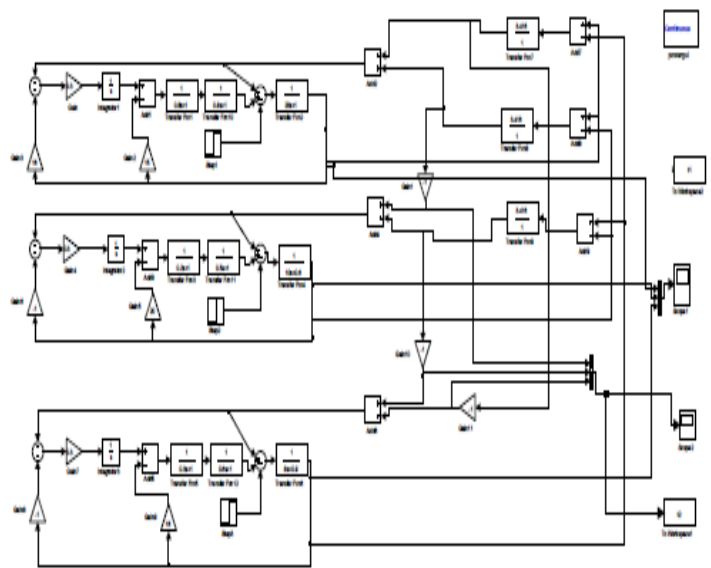

Fig. 4.15 Simulink model of three area power system without integral control

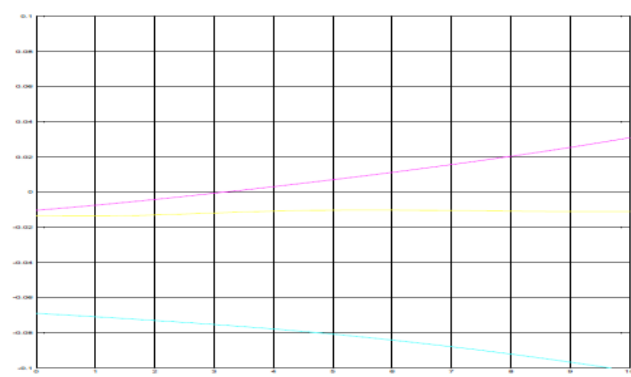

Fig. 4.16 Frequency deviation vs. time

Fig. 4.15 shows three area interconnected system without secondary loop. Fig 4.16 shows finite value of frequency which is less than the actual value. Fig.4.17 shows power change due to tie-lines on the account of deviation in the load. With the interconnection, stability is improved. Different values of parameters have been taken for fig. 4.15 .

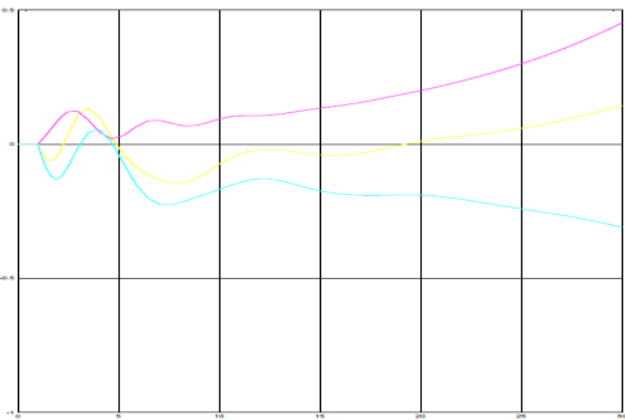

Fig. 4.17 power deviation vs. time

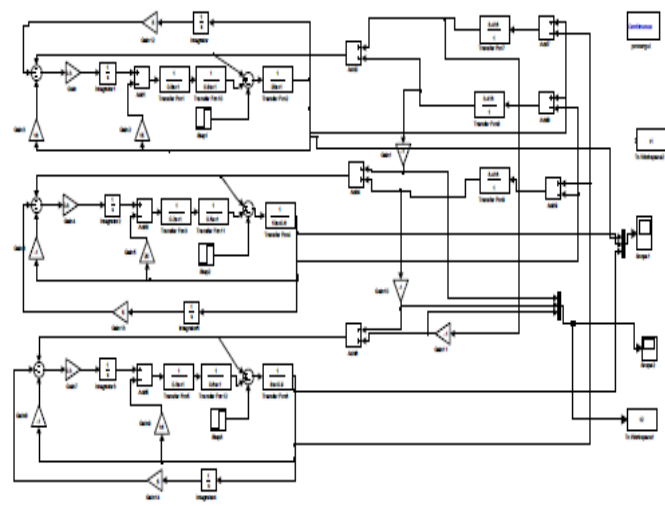

Fig. 4.18 Simulink model of three area power system without integral control 


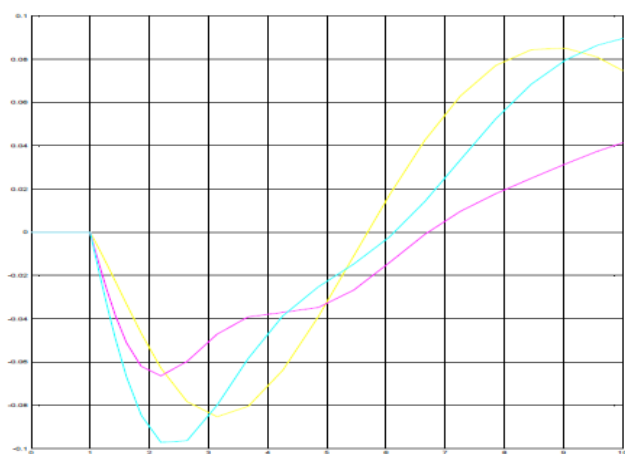

Fig. 4.19 Frequency deviation vs. time

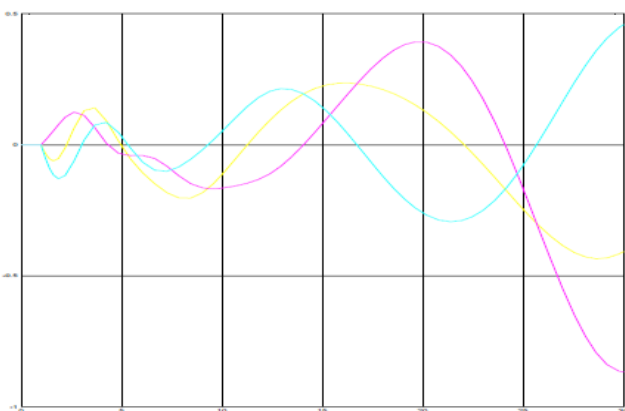

Fig. 4.20 Power deviation vs. time

Fig. 4.18 shows the simulink model of three area power system including secondary loop. change in frequency and power with respect to time are shown in fig. 4.19 and fig. 4.20. Different values of parameters have been taken for fig. 4.18 .

Fig. 4.21 shows simulink model using PID controller. PID controller is used to improve the dynamic response as well as to reduce or to improve steady-state error and to eliminate transient deviations.

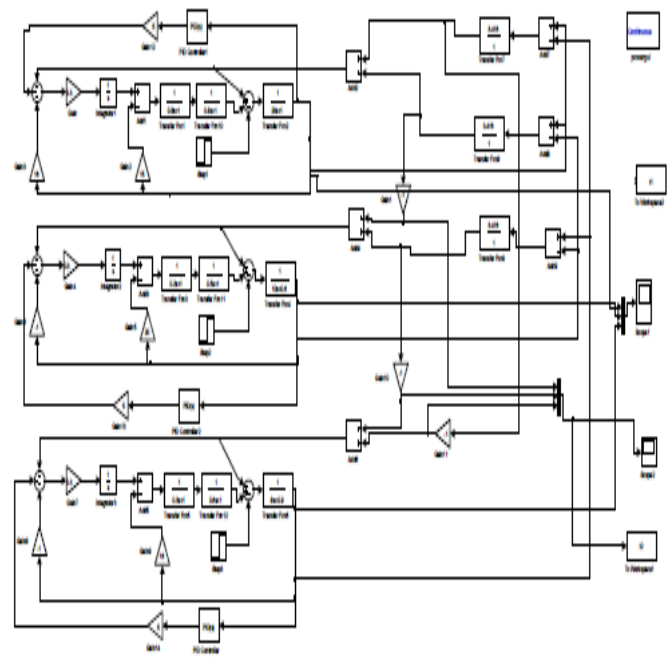

Fig. 4.21 Simulink model using PID

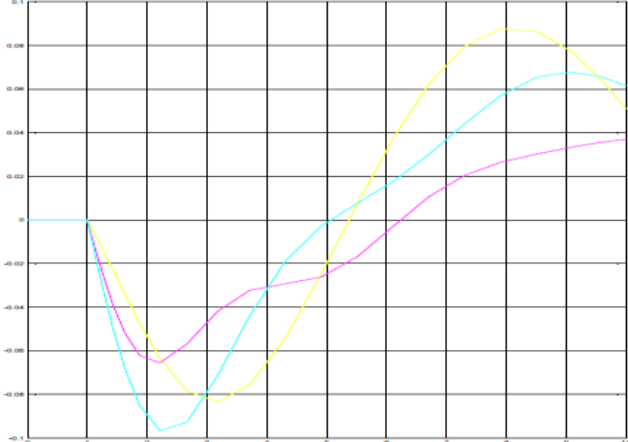

Fig. 4.22 Frequency deviation vs. time

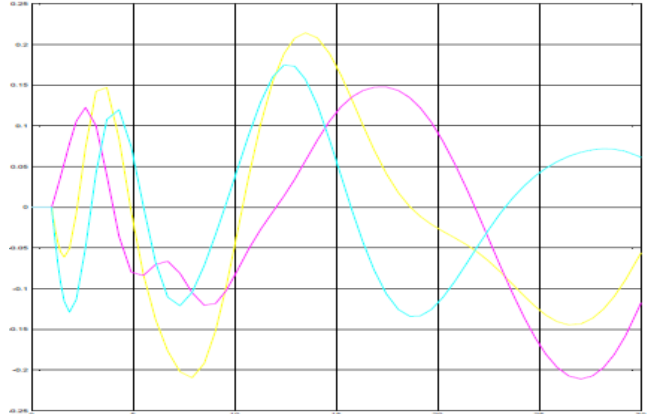

Fig. 4.23 Power deviation vs. time

\section{CONCLUSION}

Thus, SIMULINK models help us to understand the principle of automatic load frequency control..In single area system, the drift in frequency is settle down near to limited value. In two area power system, the drift in frequency is made to zero. In three area power system, by using interconnection the stability is improved. By using PID controller in single area, two area and for three area the settling time is reduced, less oscillations occurs and good time response.

\section{REFERENCES}

[1] Fosha, C.E. and Elgerd, O.I., The megawatt-frequency control problem: a New Approach via Optimal Control Theory, IEEE Trans. Power Apparatus and Systems, 1970, 89(4): 563-577.

[2] Kothari, D.P. and Nagrath, I.J. Modern Power System Analysis, 1st Edition, McGraw-Hill, New York, 2008.

[3] Kundur P. Power System Stability \& Control, McGraw-Hill, New York, 1994

4] Hassan A. Yousef, Khalfan AL-Kharusi, Mohammed H. Albadi, Nasser Hosseinzadeh, Load Frequency Control of a Multi-Area Power System: An Adaptive Fuzzy Logic Approach, IEEE Transactions on Power Systems, vol. 29, no. 4, July 2014

[5] Shayeghi H, Shayanfar HA, Jalili A. Load frequency control strategies: a state of-the-art survey for the researcher. Energy Conversion and Management, 2009, 50(2): 344-353

[6] Tan W. Decentralized load frequency controller analysis and tuning for multi-area power systems, Energy Conversion and Management , 2011,52(5): 2015-2023.

[7] Al-Badi, M., Awlad Thani, A. Al-Omeiri, B. and Ellithy, K.A. Comparative Study of Load Frequency Controller Design for Interconnected Power Systems, The Journal for Scientific Research-Science and Technology, Sultan Qaboos University,m 2002, 7: 81-90.

[8] Chan, W.C. and Hsu, Y.Y., Automatic Generation Control of Interconnected Power Systems Using Variable Structure Controller. IEE Proc. on Generation, Transmission and Distribution Pt. C, 1981: 269-279.

[9] Feliach, A. , Optimal Decentralized Load Frequency Control, IEEE Trans. on Power Systems, 1987, 2: 379-386. 
INTERNATIONAL JOURNAL OF INNOVATIVE RESEARCH IN ELECTRICAL, ELECTRONICS, INSTRUMENTATION AND CONTROL ENGINEERING Vol. 3, Issue 8, August 2015

[10] Hiyama, T., Design of Decentralized Load Frequency Regulators for Interconnected Power Systems, IEE Proc., Pt C, 1982, 129 (1): 17 23.

[11] Hiyama, T. Optimization of Discrete-Type Load Frequency Regulator Considering Generation Rate Constraints, Proc. IEE, Pt. C, Generation, Transmission and Distribution, 1982, 129 (6): 285289.

[12] Kothari, M.L., Nanda, J., Kothari, D.P. and Das, D., Discrete-Mode Automatic Generation Control of Two-Area Reheat Thermal System with New Area Control Error, IEEE Transactions on Power Systems, 1989, 4(2): 730-738.

[13] Oysal, Y. A Comparative Study of Adaptive Load Frequency Controller Designs in a Power System with Dynamic Neural Network Models, Energy Conversion and Management 2005, 46 (15-16): 2656-2668. 